The Agriculturists 15(1):101-109(2017)ＩSSN 2304-7321 (Online), ISSN 1729-5211 (Print)

\title{
Effect of Nitrogen, Phosphorus and Potassium Fertilizers on Yield and Yield Attributes of Marigold (Tagetes patula L.)
}

\author{
R. Ahmed ${ }^{1}$, M.J. Hussain ${ }^{2}$, S. Ahmed ${ }^{3}$, M.R. Karim ${ }^{1}$ and M.A. Siddiky ${ }^{2}$ \\ ${ }^{1}$ Horticulture Research Centre, Bangladesh Agricultural Research Institute (BARI), Gazipur, \\ Bangladesh; ${ }^{2}$ Soil \& Water Management Section, Horticulture Research Centre, BARI, Gazipur, \\ Bangladesh. ${ }^{3}$ Biotechnology Division, BARI, Gazipur, Bangladesh \\ *Corresponding author and Email: hussainmdjamal@ymail.com
}

Received: 22 February 2017

Accepted: 12 June 2017

\begin{abstract}
An experiment was conducted at the research field of Horticulture Research Centre, BARI, Gazipur during Rabi season of 2012-13 to 2014-15 to evaluate the yield and yield attributes of Marigold (var. BARI Marigold-1) to different doses of $\mathrm{N}, \mathrm{P}$ and $\mathrm{K}$ fertilizers and to find out the optimum and economic doses of NPK for maximizing flower yield. Eleven treatments as $T_{1}, T_{2}, T_{3}, \ldots \ldots, T_{10}$ and $T_{11}$ comprising with four levels of fertilizer nutrients each of $\mathrm{N}\left(0,60,90\right.$ and $\left.120 \mathrm{~kg} \mathrm{ha}^{-1}\right), \mathrm{P}(0,30,40$ and $\left.50 \mathrm{~kg} \mathrm{ha}^{-1}\right)$ and $\mathrm{K}\left(0,60,90\right.$ and $\left.120 \mathrm{~kg} \mathrm{ha}^{-1}\right)$ along with a blanket dose of $2 \mathrm{~kg} \mathrm{~B}$ and $4 \mathrm{~kg} \mathrm{Zn} \mathrm{ha}{ }^{-1}$. The experiment was conducted assigning the treatments in a randomized complete block design with three replications. Flower yield and yield attributes of marigold significantly increased with NPK fertilizer for all three years. The significantly highest flower yield $\left(22.25,27.38\right.$ and 25.15 ton ha $\left.{ }^{-1}\right)$ was obtained from $\mathrm{T}_{3}$ treatment applying the nutrients $\mathrm{N}_{90} \mathrm{P}_{40} \mathrm{~K}_{90} \mathrm{~kg} \mathrm{ha}^{-1}$ along with blanket dose of $2 \mathrm{Kg} \mathrm{B}$ and $4 \mathrm{~kg} \mathrm{Zn} \mathrm{ha}^{-1}$ for the years 2012-13, 2013-14 and 2014-15, respectively which was statistically identical with $\mathrm{T}_{4}$ treatment $\left(\mathrm{N}_{120} \mathrm{P}_{40} \mathrm{~K}_{90} \mathrm{~kg} \mathrm{ha}^{-1}\right)$ for the year 2012-13, but significantly different from all other treatments for the years 2013-14 and 2014-15, respectively. Flower yields were increased in $\mathrm{T}_{3}$ treatment $\left(\mathrm{N}_{90} \mathrm{P}_{40} \mathrm{~K}_{90} \mathrm{~kg} \mathrm{ha}^{-1}\right)$ by 81.34, 62.53 and 49.53\%; 146.00, 119.39 and $108.84 \%$ and 121.20, 92.13 and $84.11 \%$ over their control in respect to the years 2012-13, 2013-14 and 2014-15. The highest benefit-cost ratio 7.14 was obtained from $\mathrm{T}_{3}\left(\mathrm{~N}_{90} \mathrm{P}_{40} \mathrm{~K}_{90} \mathrm{~kg} \mathrm{ha}^{-1}\right)$ followed by $\mathrm{T}_{4}(6.53)$ treatment. From the quadratic regression equation averaging three years data the optimum and economic doses 103.75 and $102.44 \mathrm{~kg} \mathrm{~N} ; 36.67$ and $36.31 \mathrm{~kg} \mathrm{P}$ and 90.10 and $88.43 \mathrm{~kg} \mathrm{~K}$, respectively were found which could be recommended for marigold production in Grey Terrace Soil of Joydebpur under AEZ 28.
\end{abstract}

Keywords: Marigold, NPK fertilizer, Optimum and economic dose.

\section{Introduction}

Flowers have gained very high economic values for their eternal beauty, love and tranquility. Flower is used for religious offering, decoration, pharmaceuticals, foods supplement and coloring agent for cosmetics (Priyanka et al., 2013).
Marigold (Tagetes patula $\mathrm{L}$ ) is one of the most important decorative plants and it has many medicinal values also. Marigold gained popularity amongst flower growers and dealers on account of its easy culture and wide adaptability. Its habit of free flowering, short duration to produce marketable flowers, wide 
spectrum of attractive color, shape, size and good keeping quality attracted the attention of flower growers. Marigold has been adapted to different types of soil conditions and is growing successfully in different types of soil. However, a deep, fertile, sandy loam, and friable soil having good water holding capacity, well drained and near to neutral in reaction $(\mathrm{pH} 7.0$ 7.5) is most desirable for marigold cultivation (Bose \&Yadav, 1998). Mild climate during growing period $\left(14.5-28.6^{\circ} \mathrm{C}\right)$ greatly improved flowering while higher temperatures (26.2$34.4^{\circ} \mathrm{C}$ ) adversely affected flower production (Yadav and Bose, 1998).

Marigold has long been cultivating in all areas of Bangladesh. Fertilizer is an essential key input for production and productivity of this crop. But its fertilizer requirement for cultivation is still not well documented regionally. Research has shown that fertilizer input contributes about 40$50 \%$ of total yield increase for most crops (Dass and Mitali, 2016). In fact $50 \%$ of the total increase in crop production comes from the use of fertilizers and rest from all other factors combined together. Good flower production requires optimal fertilizer management to attain a high ornamental value and to reduce production cost of a plant (Zhang et al., 2012). Nitrogen, phosphorus and potassium play a vital role in the production of good quality flowers. Nitrogen and phosphorus are required in sufficient quantities to attain better growth of marigold and promote flowering (Pandey and Mishra, 2005). It was reported that nitrogen, phosphorus, and potassium greatly influence the growth, flower, and tuber production of tuberose (Khan et al., 2012).

Nitrogen is considered to be the most crucial because it is a constituent of protein and nucleic acid which is helpful in plant growth as well as to promote rapid growth (Haque, 2001). Potassium has been reported to be involved in synthesis of peptide bond, protein and carbohydrate metabolism and also participates in rapid cell division and differentiation (Belorkar et al., 1992). Phosphorus and potash contents resulted in maximum increase in nutrient uptake by virtue of more photosynthesis through more chlorophyll formation with an increased leaf area (Belorker et al., 1992). Potassium requirements are high, and its presence in the plant favorably affects growth and flower color (Vaněk et al., 2012). Nitrogen applied as fertilizer is the main sources used to meet the $\mathrm{N}$ requirements of plant growth (Konnerup and Brix, 2010). The highest level of nitrogen has pronounced effect on number of flowers (Khan et al., 1999). According to Beata (2011), the marigold does not require intensive mineral fertilization, and high doses of nitrogen result in the decrease of yield of flower head. Application of macro and micronutrients also increase the flower quality and total flower production. In the light of above information a fertilizer recommendation with optimum doses of $\mathrm{N}, \mathrm{P}$ and $\mathrm{K}$ for marigold production and cultural practices is necessary for this area. Hence, the present study was undertaken to evaluate the response of marigold to NPK fertilizers and to find out their optimum and economic doses for maximizing yield of marigold in Grey Terrace soil of Joydebpur, Gazipur.

\section{Materials and Methods}

The experiments were conducted at the Horticultural Research Farm, BARI, Gazipur during Rabi season of 2012-13 to 2014-15 to evaluate the response of marigold yield and yield attributes to $\mathrm{N}, \mathrm{P}$ and $\mathrm{K}$ fertilizer and to find out the optimum and economic doses of NPK for maximizing yield of marigold. The initial soil characteristics of the experimental field were shown in Table 1. The soil test values showed that the experimental soil was deficient in nutrients especially of $\mathrm{N}, \mathrm{P}$ and $\mathrm{K}$. The experiment was conducted following randomized complete block design with three replications. Treatments as $\mathrm{T}_{1}, \quad \mathrm{~T}_{2}, \mathrm{~T}_{3}, \ldots \ldots, \mathrm{T}_{10}$ and $\mathrm{T}_{11}$ comprising with four levels of fertilizer nutrients each of $\mathrm{N}\left(0,60,90\right.$ and $\left.120 \mathrm{~kg} \mathrm{ha}^{-1}\right), \mathrm{P}(0,30$, 40 and $\left.50 \mathrm{~kg} \mathrm{ha}^{-1}\right)$ and $\mathrm{K}(0,60,90$ and $120 \mathrm{~kg}$ $\mathrm{ha}^{-1}$ ) along with a blanket dose of $2 \mathrm{~kg} \mathrm{~B}$ and 4 $\mathrm{kg} \mathrm{Zn} \mathrm{ha-1.}$ 
The unit plot size was $2 \mathrm{~m} \times 2 \mathrm{~m}$. The row to row and plant to plant spacing were $50 \mathrm{~cm}$ and 40 $\mathrm{cm}$, respectively. Every plot except control had received a blanket dose of $2 \mathrm{~kg} \mathrm{~B}$ and $4 \mathrm{~kg} \mathrm{Zn}$ $\mathrm{ha}^{-1}$. Urea, TSP, MoP, boric acid and zinc sulphate were used as a source of $\mathrm{N}, \mathrm{P}, \mathrm{K}, \mathrm{B}$ and $\mathrm{Zn}$, respectively. All $\mathrm{P}, \mathrm{K}, \mathrm{B}, \mathrm{Zn}$ and $1 / 3^{\text {rd }} \mathrm{N}$ were applied at the time of final land preparation and the remaining $2 / 3^{\text {rds }} \mathrm{N}$ were applied in two equal splits each at 30 and 45 days after transplanting. Thirty days old seedlings of marigold (var. BARI Marigold-1) were planted on $2^{\text {nd }}$ December, 2012; $17^{\text {th }}$ December, 2013 and $07^{\text {th }}$ November, 2014 for the years, respectively. All intercultural operations such as three weeding were made and irrigation was done at 7 days interval up to harvesting.

The flower was harvested four times from $13^{\text {th }}$ February to $8^{\text {th }}$ March, 2013, $13^{\text {th }}$ February to $12^{\text {th }}$ March, 2014 and $24^{\text {th }}$ January to $2^{\text {nd }}$ March, 2015 , respectively. The data on plant height, number of flower per plant and yield contributing characters were recorded from ten randomly selected plants from each treatment. Data on yield and yield contributing characters were analyzed statistically and the mean differences were tested by Duncan's Multiple Range Test (Steel and Torrie, 1960). Soil pH was measured by a glass calomel electrode (Jackson, 1958). Total $\mathrm{N}$ was determined by modified
Kjeldhl method and $\mathrm{Ca}, \mathrm{Mg}$ were by $\mathrm{KCL}$ extractable method (Hunter, 1984).

\section{Results and Discussion}

\subsection{NPK on yield and yield attributes}

Effect of different levels of NPK on the yield and yield attributes of marigold were presented in Table 2. Different treatment combination showed a significant influence on yield and yield contributing characters of marigold. The highest plant height, number of flowers plant ${ }^{-1}$, flower diameter, individual flower weight and yield per hectare were recorded in $\mathrm{T}_{3}\left(\mathrm{~N}_{90} \mathrm{P}_{40} \mathrm{~K}_{90} \mathrm{~kg} \mathrm{ha}^{-1}\right)$ treatment which received $90 \mathrm{~kg} \mathrm{~N} 40 \mathrm{~kg} \mathrm{P}$ and $90 \mathrm{~kg} \mathrm{~K} \mathrm{ha}{ }^{-1}$ and the lowest values were in respective control $\left(\mathrm{T}_{11}\right)$ for all three years (Tables 2 and 3). The maximum plant heights $(70.53,72.80$ and $56.67 \mathrm{~cm})$ were recorded in $\mathrm{T}_{3}$ treatment that was statistically similar to that in $\mathrm{T} 4\left(\mathrm{~N}_{120} \mathrm{P}_{40} \mathrm{~K}_{90} \mathrm{~kg} \mathrm{ha}^{-1}\right)$ for 2012-13 and 2013-14, respectively but it was similar to $\mathrm{T} 4$ and $\mathrm{T}_{2}$ $\left(\mathrm{N}_{60} \mathrm{P}_{40} \mathrm{~K}_{90} \mathrm{~kg} \mathrm{ha}^{-1}\right)$ for 2014-15.

These results were in agreement with the findings of Beata (2011) who reported that marigold does not require intensive mineral fertilization, and high doses of nitrogen result in the decrease of yield of flowers. Nitrogen promotes rapid growth as a constituent of protein and nucleic acid (Haque, 2001).

Table 1. Initial soil nutrient status of the experimental site of HRC Farm, Joydebpur, Gazipur

\begin{tabular}{lccc}
\hline Nutrient & Soil test value & Critical level & Soil test interpretation \\
\hline $\mathrm{pH}$ & 6.2 & - & Slightly acidic \\
Organic matter $(\%)$ & 0.95 & - & Low \\
$\mathrm{Ca}(\mathrm{c}-\mathrm{mol} / \mathrm{kg}$ soil $)$ & 1.12 & 2.0 & Low \\
$\mathrm{Mg}(\mathrm{c}-\mathrm{mol} / \mathrm{kg}$ soil $)$ & 0.60 & 0.5 & Medium \\
Total N $(\%)$ & 0.08 & 0.12 & Medium \\
Available P $(\mu \mathrm{g} / \mathrm{g})$ & 9 & 7 & Low \\
$\mathrm{K}(\mathrm{c}-\mathrm{mol} / \mathrm{kg} \mathrm{soil})$ & 0.17 & 0.12 & Low \\
$\mathrm{S}(\mu \mathrm{g} / \mathrm{g})$ & 11.2 & 10 & Low \\
$\mathrm{Zn}(\mu \mathrm{g} / \mathrm{g})$ & 1.4 & 0.6 & Low \\
$\mathrm{B}(\mu \mathrm{g} / \mathrm{g})$ & 0.10 & 0.2 & Low \\
\hline
\end{tabular}


Table 2. Effect of different fertilizer treatments on yield and yield attributes of marigold

\begin{tabular}{|c|c|c|c|c|c|c|c|c|c|}
\hline \multirow{2}{*}{$\begin{array}{l}\text { Treatments } \\
(\mathrm{Kg} / \mathrm{ha})\end{array}$} & \multicolumn{3}{|c|}{ Plant height $(\mathrm{cm})$} & \multicolumn{3}{|c|}{ Flower plant $^{-1}$ (no.) } & \multicolumn{3}{|c|}{ Flower diameter $(\mathrm{cm})$} \\
\hline & $2012-13$ & 2013-14 & 2014-15 & $2012-13$ & 2013-14 & $2014-15$ & $2012-13$ & 2013-14 & 2014-15 \\
\hline $\mathrm{T}_{1}=\mathrm{N}_{0} \mathrm{P}_{40} \mathrm{~K}_{90}$ & $55.75 \mathrm{~h}$ & 48.95hi & $37.35 \mathrm{fg}$ & $18.62 \mathrm{f}$ & $11.75 \mathrm{~g}$ & $15.19 \mathrm{fg}$ & $7.19 \mathrm{~d}$ & $6.90 \mathrm{fg}$ & $7.05 \mathrm{de}$ \\
\hline $\mathrm{T}_{2}=\mathrm{N}_{60} \mathrm{P}_{40} \mathrm{~K}_{90}$ & $66.55 b c$ & $66.90 \mathrm{bc}$ & $51.72 \mathrm{ab}$ & $24.10 \mathrm{bc}$ & $17.75 b$ & $20.93 a-c$ & 7.96ab & $8.55 \mathrm{a}-\mathrm{c}$ & $8.26 \mathrm{ab}$ \\
\hline $\mathrm{T}_{3}=\mathrm{N}_{90} \mathrm{P}_{40} \mathrm{~K}_{90}$ & $70.53 a$ & $72.80 \mathrm{a}$ & $56.67 \mathrm{a}$ & $25.87 \mathrm{a}$ & $19.50 \mathrm{a}$ & $22.69 \mathrm{a}$ & $8.55 a$ & $9.10 \mathrm{a}$ & $8.83 \mathrm{a}$ \\
\hline $\mathrm{T}_{4}=\mathrm{N}_{120} \mathrm{P}_{40} \mathrm{~K}_{90}$ & $68.60 \mathrm{ab}$ & $69.85 \mathrm{ab}$ & $54.22 \mathrm{ab}$ & $24.40 \mathrm{ab}$ & $18.65 \mathrm{ab}$ & $21.53 \mathrm{ab}$ & 7.98ab & $8.78 \mathrm{ab}$ & $8.38 \mathrm{ab}$ \\
\hline $\mathrm{T}_{5}=\mathrm{N}_{90} \mathrm{P}_{0} \mathrm{~K}_{90}$ & $56.95 \mathrm{gh}$ & $50.25 \mathrm{~g}-\mathrm{i}$ & $38.6 f g$ & $19.35 \mathrm{fg}$ & $12.25 \mathrm{fg}$ & $15.80 \mathrm{fg}$ & $7.42 b-d$ & $7.08 \mathrm{e}-\mathrm{g}$ & $7.25 \mathrm{c}-\mathrm{e}$ \\
\hline $\mathrm{T}_{6}=\mathrm{N}_{90} \mathrm{P}_{30} \mathrm{~K}_{90}$ & $59.95 \mathrm{e}-\mathrm{g}$ & $54.55 \mathrm{fg}$ & $42.25 \mathrm{~d}-\mathrm{f}$ & $21.25 \mathrm{de}$ & $13.68 \mathrm{de}$ & $17.47 \mathrm{def}$ & $7.62 b-d$ & $7.65 \mathrm{~d}-\mathrm{f}$ & $7.64 b-d$ \\
\hline $\mathrm{T}_{7}=\mathrm{N}_{90} \mathrm{P}_{50} \mathrm{~K}_{90}$ & $61.15 \mathrm{ef}$ & $57.35 \mathrm{ef}$ & $44.25 \mathrm{c}-\mathrm{e}$ & $22.55 \mathrm{~cd}$ & $14.65 d$ & $18.60 \mathrm{c}-\mathrm{e}$ & $7.82 \mathrm{bc}$ & $7.85 \mathrm{c}-\mathrm{e}$ & $7.83 b-d$ \\
\hline $\mathrm{T}_{8}=\mathrm{N}_{90} \mathrm{P}_{40} \mathrm{~K}_{0}$ & $57.85 f-h$ & $52.95 f-h$ & 40.40ef & $19.85 \mathrm{ef}$ & $12.95 \mathrm{ef}$ & $16.85 \mathrm{ef}$ & $7.59 b-d$ & $7.25 \mathrm{ef}$ & $7.42 \mathrm{~b}-\mathrm{e}$ \\
\hline $\mathrm{T}_{9}=\mathrm{N}_{90} \mathrm{P}_{40} \mathrm{~K}_{60}$ & $62.35 \mathrm{de}$ & $60.55 \mathrm{de}$ & $46.45 \mathrm{~cd}$ & $22.95 b c$ & $15.75 \mathrm{c}$ & $19.35 b-e$ & $7.85 b c$ & $8.11 b-d$ & $7.98 \mathrm{a}-\mathrm{d}$ \\
\hline $\mathrm{T}_{10}=\mathrm{N}_{90} \mathrm{P}_{40} \mathrm{~K}_{120}$ & $64.75 \mathrm{~cd}$ & $63.75 \mathrm{~cd}$ & $49.25 b c$ & $23.35 \mathrm{bc}$ & $16.55 \mathrm{c}$ & $19.95 b-d$ & 7.94ab & $8.28 b-d$ & $8.11 \mathrm{a}-\mathrm{c}$ \\
\hline $\mathrm{T}_{11}=$ Native fertility & $52.35 \mathrm{i}$ & $45.80 \mathrm{i}$ & $34.07 \mathrm{~g}$ & $17.05 \mathrm{~g}$ & $10.50 \mathrm{~h}$ & $13.78 \mathrm{~g}$ & $6.56 \mathrm{e}$ & $6.35 \mathrm{~g}$ & $6.46 \mathrm{e}$ \\
\hline $\mathrm{CV}(\%)$ & 8.85 & 9.45 & 7.75 & 9.79 & 9.55 & 8.33 & 8.93 & 8.26 & 9.05 \\
\hline
\end{tabular}

Means having common letter in a column are not significantly different by DMRT at $5 \%$ level.

Table 3. Effect of different fertilizer treatments on yield and yield attributes of marigold

\begin{tabular}{|c|c|c|c|c|c|c|c|}
\hline \multirow{2}{*}{$\begin{array}{l}\text { Treatments } \\
\left(\mathrm{Kg} \mathrm{ha}^{-1}\right)\end{array}$} & \multicolumn{3}{|c|}{ Individual flower weight (g) } & \multicolumn{3}{|c|}{ Yield $\left(\right.$ Ton ha $\left.{ }^{-1}\right)$} & \multirow{2}{*}{$\begin{array}{l}\text { Average yield } \\
\left(\text { Ton } \mathrm{ha}^{-1}\right)\end{array}$} \\
\hline & $2012-13$ & $2013-14$ & 2014-15 & $2012-13$ & 2013-14 & $2014-15$ & \\
\hline $\mathrm{T}_{1}=\mathrm{N}_{0} \mathrm{P}_{40} \mathrm{~K}_{90}$ & $13.68 \mathrm{~g}$ & $17.25 \mathrm{~g}$ & $15.47 \mathrm{fg}$ & $12.27 \mathrm{~h}$ & $11.13 \mathrm{~h}$ & $11.37 \mathrm{~g}$ & $11.48 \mathrm{~g}$ \\
\hline $\mathrm{T}_{2}=\mathrm{N}_{60} \mathrm{P}_{40} \mathrm{~K}_{90}$ & $19.31 \mathrm{bc}$ & $25.75 b$ & $22.53 a-c$ & $19.45 \mathrm{bc}$ & $22.85 b c$ & $20.82 \mathrm{c}$ & $20.93 c$ \\
\hline $\mathrm{T}_{3}=\mathrm{N}_{90} \mathrm{P}_{40} \mathrm{~K}_{90}$ & $21.49 \mathrm{a}$ & $28.08 \mathrm{a}$ & $24.78 \mathrm{a}$ & $22.25 \mathrm{a}$ & $27.38 \mathrm{a}$ & $25.15 \mathrm{a}$ & $24.82 \mathrm{a}$ \\
\hline $\mathrm{T}_{4}=\mathrm{N}_{120} \mathrm{P}_{40} \mathrm{~K}_{90}$ & $20.43 \mathrm{ab}$ & $26.45 b$ & $23.44 \mathrm{ab}$ & $21.05 \mathrm{a}$ & $24.66 b$ & $23.19 b$ & $22.86 b$ \\
\hline $\mathrm{T}_{5}=\mathrm{N}_{90} \mathrm{P}_{0} \mathrm{~K}_{90}$ & $14.35 f g$ & $18.75 f$ & $16.55 \mathrm{e}-\mathrm{g}$ & $13.69 \mathrm{~g}$ & $12.48 \mathrm{gh}$ & $13.09 \mathrm{f}$ & $12.98 \mathrm{f}$ \\
\hline $\mathrm{T}_{6}=\mathrm{N}_{90} \mathrm{P}_{30} \mathrm{~K}_{90}$ & $16.15 \mathrm{e}^{\circ}$ & $21.85 \mathrm{~d}$ & $18.95 \mathrm{c}-\mathrm{f}$ & $15.63 \mathrm{f}$ & $14.95 \mathrm{fg}$ & $15.29 \mathrm{e}$ & $15.18 \mathrm{e}$ \\
\hline $\mathrm{T}_{7}=\mathrm{N}_{90} \mathrm{P}_{50} \mathrm{~K}_{90}$ & $16.42 \mathrm{de}$ & $22.35 d$ & $19.38 \mathrm{c}-\mathrm{e}$ & $16.16 \mathrm{ef}$ & $16.37 \mathrm{ef}$ & $15.93 \mathrm{e}$ & $16.04 \mathrm{e}$ \\
\hline $\mathrm{T}_{8}=\mathrm{N}_{90} \mathrm{P}_{40} \mathrm{~K}_{0}$ & $15.75 \mathrm{ef}$ & $20.25 \mathrm{e}$ & $17.96 \mathrm{~d}-\mathrm{f}$ & $14.88 \mathrm{fg}$ & $13.11 \mathrm{gh}$ & $13.66 \mathrm{f}$ & $13.77 \mathrm{f}$ \\
\hline $\mathrm{T}_{9}=\mathrm{N}_{90} \mathrm{P}_{40} \mathrm{~K}_{60}$ & $17.92 \mathrm{~cd}$ & $23.95 c$ & $20.93 b-d$ & $17.51 \mathrm{de}$ & $18.86 \mathrm{de}$ & $17.85 \mathrm{~d}$ & $17.96 \mathrm{~d}$ \\
\hline $\mathrm{T}_{10}=\mathrm{N}_{90} \mathrm{P}_{40} \mathrm{~K}_{120}$ & $18.09 \mathrm{~cd}$ & $24.45 \mathrm{c}$ & $21.27 \mathrm{a}-\mathrm{d}$ & $18.55 \mathrm{~cd}$ & $20.23 \mathrm{~cd}$ & $19.06 \mathrm{~d}$ & $19.17 d$ \\
\hline $\mathrm{T}_{11}=$ Native fertility & $12.05 \mathrm{~h}$ & $15.58 \mathrm{~h}$ & $13.82 \mathrm{~g}$ & $10.85 \mathrm{i}$ & $8.17 \mathrm{i}$ & $9.18 \mathrm{~h}$ & $9.29 \mathrm{~h}$ \\
\hline $\mathrm{CV}(\%)$ & 9.90 & 10.15 & 9.45 & 9.97 & 11.25 & 4.98 & 4.34 \\
\hline
\end{tabular}

Means having common letter in a column are not significantly different by DMRT at $5 \%$ level. 
Table 4. Single effect of N, P and K on yield of marigold

\begin{tabular}{|c|c|c|c|c|c|c|c|c|}
\hline \multirow{2}{*}{$\begin{array}{c}\text { Nutrient } \\
\text { level }(\mathrm{kg} \\
\left.\mathrm{ha}^{-1}\right)\end{array}$} & \multicolumn{4}{|c|}{ Flower yield (ton ha ${ }^{-1}$ ) } & \multicolumn{4}{|c|}{$\%$ yield increase over control } \\
\hline & $2012-13$ & $2013-14$ & $2014-15$ & Average & $2012-13$ & $2013-14$ & $2014-15$ & Average \\
\hline \multicolumn{9}{|l|}{ N level } \\
\hline 0 & 12.27 & 11.13 & 11.37 & 11.59 & - & - & - & - \\
\hline 60 & 19.45 & 22.85 & 20.82 & 21.04 & 58.52 & 105.30 & 83.11 & 82.31 \\
\hline 90 & 22.25 & 27.38 & 25.15 & 24.93 & 81.34 & 146.00 & 121.20 & 116.18 \\
\hline 120 & 21.05 & 24.66 & 23.19 & 22.97 & 71.56 & 121.56 & 103.96 & 99.03 \\
\hline \multicolumn{9}{|l|}{ P level } \\
\hline 0 & 13.69 & 12.48 & 13.09 & 13.09 & - & - & - & - \\
\hline 30 & 15.63 & 14.95 & 15.29 & 15.29 & 14.17 & 19.79 & 16.81 & 16.92 \\
\hline 40 & 22.25 & 27.38 & 25.15 & 24.93 & 62.53 & 119.39 & 92.13 & 91.35 \\
\hline 50 & 16.16 & 16.37 & 15.93 & 16.15 & 18.04 & 31.16 & 21.70 & 23.63 \\
\hline \multicolumn{9}{|l|}{ K level } \\
\hline 0 & 14.88 & 13.11 & 13.66 & 13.88 & - & - & - & - \\
\hline 60 & 17.51 & 18.86 & 17.85 & 18.07 & 17.67 & 43.85 & 30.67 & 30.73 \\
\hline 90 & 22.25 & 27.38 & 25.15 & 24.93 & 49.53 & 108.84 & 84.11 & 80.83 \\
\hline 120 & 18.55 & 20.23 & 19.06 & 19.28 & 24.66 & 54.30 & 39.53 & 39.50 \\
\hline
\end{tabular}

Table 5. Economic analysis of marigold production under different fertilizer treatments

\begin{tabular}{cccccccc}
\hline $\begin{array}{c}\text { Treatm } \\
\text { ents }\end{array}$ & $\begin{array}{c}\text { Fixed cost } \\
\left(\text { Tk. ha }^{-1}\right)\end{array}$ & $\begin{array}{c}\text { Variable cost, } \\
\text { Fertilizer only } \\
\left(\text { Tk. ha }^{-1}\right)\end{array}$ & $\begin{array}{c}\text { Total cost } \\
\left(\text { Tk. ha }^{-1}\right)\end{array}$ & $\begin{array}{c}\text { Yield } \\
\left.\text { ton ha }^{-1}\right)\end{array}$ & $\begin{array}{c}\text { Price of } \\
\text { Marigold } \\
\left.\text { Tk. ton }^{-1}\right)\end{array}$ & $\begin{array}{c}\text { Gross } \\
\text { return } \\
\left(\text { Tk. ha }^{-1}\right)\end{array}$ & BCR \\
\hline $\mathrm{T}_{1}$ & $1,57,500$ & 12,380 & $1,69,880$ & 11.48 & 50,000 & 574000 & 3.38 \\
$\mathrm{~T}_{2}$ & $1,57,500$ & 14,980 & $1,72,480$ & 20.93 & 50,000 & 1046500 & 6.07 \\
$\mathrm{~T}_{3}$ & $1,57,500$ & 16,280 & $1,73,780$ & 24.82 & 50,000 & 1241000 & 7.14 \\
$\mathrm{~T}_{4}$ & $1,57,500$ & 17,580 & $1,75,080$ & 22.86 & 50,000 & 1143000 & 6.53 \\
$\mathrm{~T}_{5}$ & $1,57,500$ & 11,880 & $1,69,380$ & 12.98 & 50,000 & 649000 & 3.83 \\
$\mathrm{~T}_{6}$ & $1,57,500$ & 15,180 & $1,72,680$ & 15.18 & 50,000 & 759000 & 4.40 \\
$\mathrm{~T}_{7}$ & $1,57,500$ & 17,380 & $1,74,880$ & 16.04 & 50,000 & 802000 & 4.59 \\
$\mathrm{~T}_{8}$ & $1,57,500$ & 12,140 & $1,69,640$ & 13.77 & 50,000 & 688500 & 4.06 \\
$\mathrm{~T}_{9}$ & $1,57,500$ & 14,900 & $1,72,400$ & 17.96 & 50,000 & 898000 & 5.21 \\
$\mathrm{~T}_{10}$ & $1,57,500$ & 17,660 & $1,75,160$ & 19.17 & 50,000 & 958500 & 5.47 \\
$\mathrm{~T}_{11}$ & $1,57,500$ & - & $1,57,500$ & 9.29 & 50,000 & 464500 & 2.95 \\
\hline
\end{tabular}

Labor + Seedling + Pesticide/insecticide + Irrigation $(37500+100000+5000+15000=157500 /-)$ Labour $=150 \times$ 250/- =37500/-, Seedlings=50000 $\times$ @ 2/- =1, 00,000/- , Price $=$ Marigold Tk. $50 \mathrm{~kg}^{-1}$, Urea $=\mathrm{Tk} \cdot 20 \mathrm{~kg}^{-1}, \mathrm{TSP}=$ Tk. $22 \mathrm{~kg}^{-1}, \mathrm{MoP}=$ Tk. $23 \mathrm{~kg}^{-1}$, Boric Acid = Tk. $195 \mathrm{~kg}^{-1}$, Zinc Sulphate $=$ Tk. $125 \mathrm{~kg}^{-1}$

This rapid growth is because of higher concentration of nitrogen, which has tendency to increase leaf cell number and cell size with an overall increase in leaf production as reported by Meyer et al. (1973). Potassium enhances the synthesis and translocation of carbohydrate; whereas phosphorus encourages cell walls and length of plant (Henry, 1982). The number of flowers plant ${ }^{-1}(25.87,19.50$ and 22.69), diameter of flower $(8.55,9.10$ and $8.83 \mathrm{~cm})$ and 
individual flower weight $(21.49,28.08$ and 24.78 g) were also found the highest in the $T_{3}$ treatment for three years, respectively followed by $\mathrm{T}_{4}\left(\mathrm{~N}_{120} \mathrm{P}_{40} \mathrm{~K}_{90} \mathrm{~kg} \mathrm{ha}^{-1}\right)$. As the number of branches plant $^{-1}$ were higher in the treatments with NPK, it favored in more photosynthesis and food accumulation, which might have resulted in better growth and converted vegetative growth in early stages due to balanced nutrition and also had sufficient food material to produce the flower earlier. But control treatment took more days for flowering which might be due to late emergence of flower buds. These findings are in close conformity with those reported by Mishra (1998) in gaillardia. Ahmad et al. (2004) reported early flowering in dahlia by applying urea, DAP and farm yard manure in a combination.

Flower yield was also significantly influenced by different levels of N, P and $\mathrm{K}$ fertilizers (Table 3 ) and it was increased to a maximum of 22.25 , 27.38 and 25.15 ton $\mathrm{ha}^{-1}$, respectively for $1^{\text {st }}, 2^{\text {nd }}$ and $3^{\text {rd }}$ year. Highest flower yield 22.25, 27.38 and 25.15 ton $\mathrm{ha}^{-1}$, were obtained, respectively for the years from $T_{3}$ treatment which was similar to $\mathrm{T}_{4}$ for the year 2012-13.. Average flower yield was also affected by the different nutrient levels and the maximum (24.82 ton ha ${ }^{-1}$ ) was obtained from $T_{3}$ treatment that was significantly different from rest of the treatments. These results are in agreement with the findings of Lodhi and Tiwari (1993). Application of 90,40 and $90 \mathrm{~kg}$ NPK ha ${ }^{-1}$ produced the highest flower yield of marigold (Table 3). Addition of nitrogen increased flower yield of 58.52, 81.34 and $71.56 \% ; 105.30$, 146.00 and $121.56 \%$ and $83.11,121.20$ and $103.96 \%$ by 60,90 and $120 \mathrm{~kg} \mathrm{~N} \mathrm{ha}{ }^{-1}$, respectively for the years 2012-13, 2013-14 and 2014-14 over control (Table 4). Additional of nitrogen also increased average flower yield of $82.31,116.18$ and $99.03 \%$ over control.

Nitrogen, phosphorus, and potassium greatly influence the growth, flower, and tuber production of tuberose (Khan et al., 2012). Nitrogen and phosphorus are required in sufficient quantities to attain better growth and promote flowering (Pandey and Mishra, 2005). Table 4 reveals that the effect of nitrogen was more pronounced as compared to that of $\mathrm{P}$ and $\mathrm{K}$. Flower yield of marigold was also increased progressively with added $\mathrm{P}$ and $\mathrm{K}$ fertilizer up to 40 and $90 \mathrm{~kg} \mathrm{ha}^{-1}$, respectively and further increase in $\mathrm{P}$ and $\mathrm{K}$ fertilizer tended to decrease flower yield. The average yield difference between the highest and the lowest was $91.35 \%$ and $80.83 \%$ in case of $\mathrm{P}$ and $\mathrm{K}$, respectively. Arulmozhiyan and Pappaiah (1989) stated that the increased flower production might be due to increased content of available nitrogen which promotes better vegetative growth and enhance production. Anuradha et al. (1988b) also reported significant increase in flower production due to nitrogen application. Since the absorption of nitrogen was more to promote more growth and production more phosphorus was needed accordingly and the plant might have taken more phosphorus. Anuradha et al. (1988a) also reported higher content of nitrogen and phosphorus due to increased application of nitrogen and phosphorus and their combination. The higher uptake of these mineral nutrients and their translocation to different parts might have helped in the production of higher total dry matter and flower yield.

\subsection{Regression analysis}

Single effect of N, P and K on yield of marigold shown in Table 4 reveals that the maximum average yield (24.93 ton $\mathrm{ha}^{-1}$ ) was obtained with the application of NPK @ 90, 40 and $90 \mathrm{~kg} \mathrm{ha}^{-1}$ which were $116.18,91.35$ and $80.83 \%$ higher in average over control. Regression analysis of average yield of marigold shows the quadratic functions for estimating the optimum levels of each nutrient over the different levels of NPK fertilizer (Fig. 1). Dobermann et al. (2000) stated that the optimum rate of fertilizer application to a crop is that rate which produces the maximum economic returns at the minimum cost and can be derived from a nutrient response curve. It is evident from Fig. 1 that yield of marigold increased with increasing level of fertilizer 
nutrients to a certain level and then decreased with further increase of nutrient level. The yield increment was prominent in case of $\mathrm{N}$ fertilizer application and the highest yield (22.25, 27.38 and 25.15 ton $\mathrm{ha}^{-1}$, respectively for the years) was obtained from $90 \mathrm{~kg} \mathrm{~N}, 40 \mathrm{~kg} \mathrm{P}$ and $90 \mathrm{~kg} \mathrm{~K}$ $\mathrm{ha}^{-1}$. The optimum and economic dose was found as 103.75 and $102.44 \mathrm{~kg} \mathrm{ha}^{-1}$ for $\mathrm{N}$ (Fig. 1.a) , 36.67 and $36.31 \mathrm{~kg} \mathrm{ha}^{-1}$ for $\mathrm{P}$ (Fig. 1.b) and 90.10 and $88.43 \mathrm{~kg} \mathrm{ha}^{-1}$ for $\mathrm{K}$ (Fig. 1.c), respectively which could be suggested as a recommended doses for marigold production.

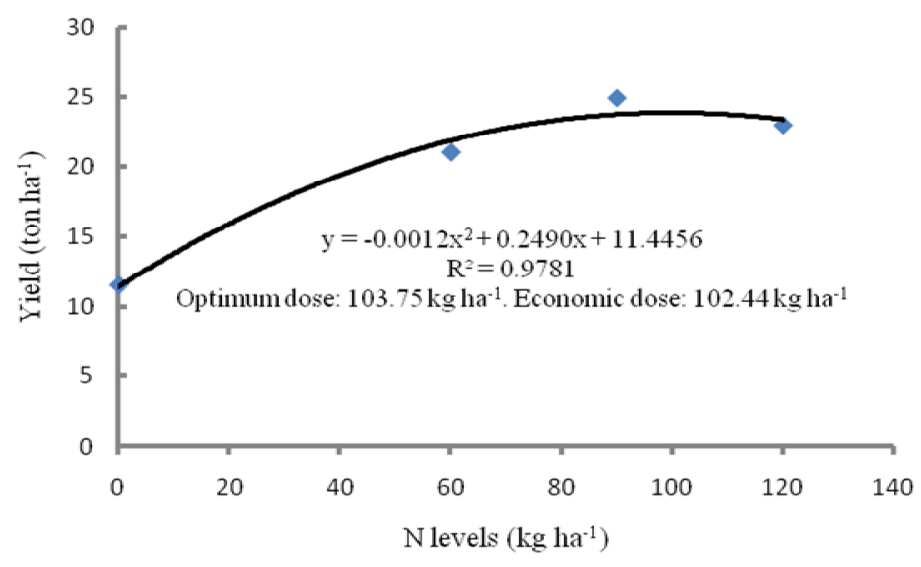

a. Optimum and economic dose of $\mathrm{N}$ for marigold production

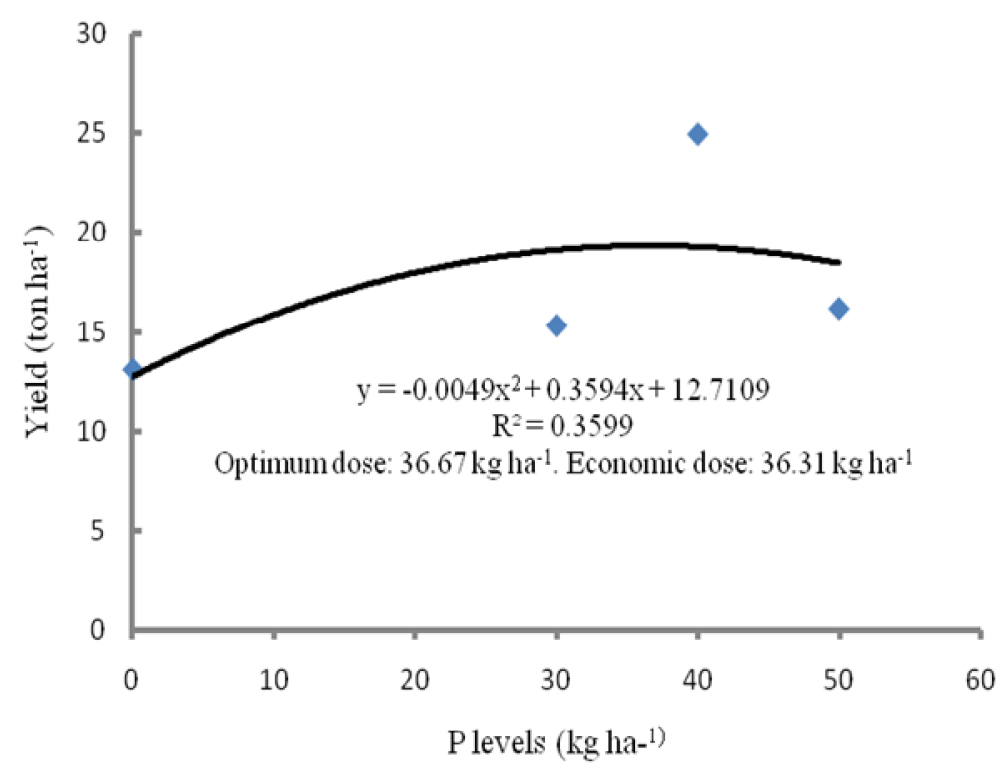

b. Optimum and economic dose of $\mathrm{P}$ for marigold production 


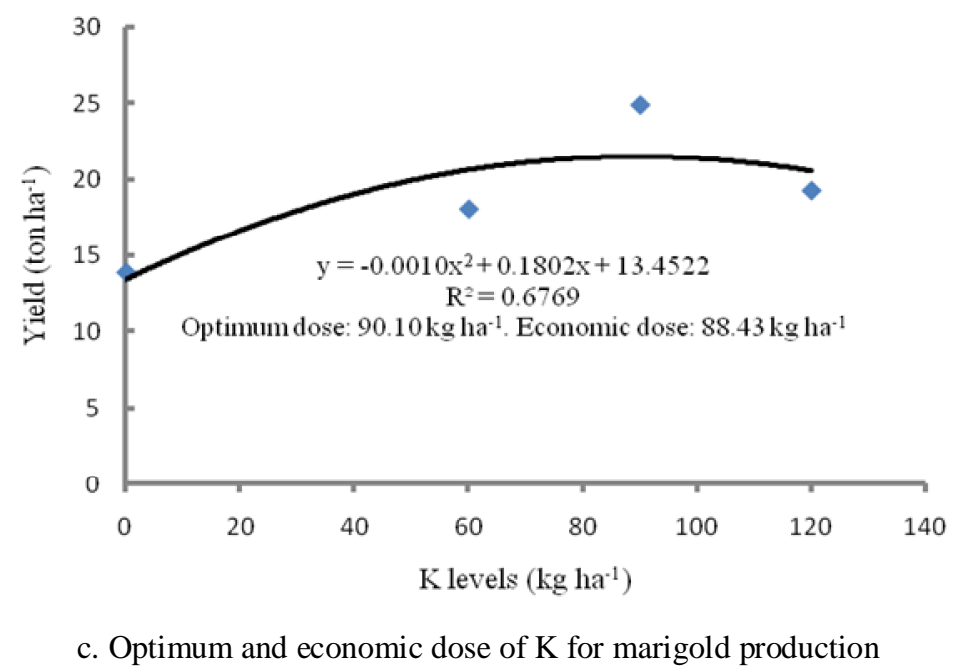

Figure 1. Functional relationship between mean yield of marigold and different levels of NPK.

\subsection{Economic comparison}

Average data pertaining to economic comparison is presented in Table 5. Maximum gross return (Tk. $1241000.00 \mathrm{ha}^{-1}$ ) was achieved with the treatment $\mathrm{T}_{3}\left(\mathrm{~N}_{90} \mathrm{P}_{40} \mathrm{~K}_{90} \mathrm{~kg} \mathrm{ha}{ }^{-1}\right)$. The highest benefit cost ratio (7.14) was also found in the treatment $T_{3}$ followed by $T_{4}$ and $T_{2}$ and the lowest 2.95 was found in control. The result revealed that the treatment $T_{3}(90,40$ and $90 \mathrm{~kg}$ NPK ha ${ }^{-1}$ was the most economically viable dose for marigold production.

\section{Conclusions}

From three years study, results have indicated that judicious nutrient management in marigold can ensure high profit. Application of 90-40-90 $\mathrm{kg} \mathrm{NPK} \mathrm{ha}{ }^{-1}$ along with blanket dose of $2 \mathrm{~kg} \mathrm{~B}$ and $4 \mathrm{~kg} \mathrm{Zn} \mathrm{ha}{ }^{-1}$ showed the best performance for marigold production. From quadratic regression equation averaging three years data $103.75 \mathrm{~kg} \mathrm{~N}, 36.67 \mathrm{~kg} \mathrm{P}$ and $90.10 \mathrm{~kg} \mathrm{~K} \mathrm{ha}^{-1}$ and $102.44 \mathrm{~kg} \mathrm{~N}, 36.31 \mathrm{~kg} \mathrm{P}$ and $88.43 \mathrm{~kg} \mathrm{~K} \mathrm{ha}^{-1}$ were found as the optimum and economic doses, respectively which could be recommended for marigold production in Grey Terrace Soil of Joydebpur under AEZ 28.

\section{References}

Ahmad, M., Khan, M. F., Hamid A. and Hussain, A. 2004. Effect of Urea, DAP and FYM on growth and flowering of Dahlia (Dahlia variabilis). International Journal of Agriculture and Biology, 6(2): 393-395.

Anuradha, K., Pampapathy, K. and Narayana, N. 1988a. Effect of $\mathrm{N}$ and $\mathrm{P}_{2} \mathrm{O}_{5}$ on the nutrient composition and uptake by marigold (Tagetes erecta L). South Indian Horticulture, 36(4): 209-211.

Anuradha, K., Pampapathy, K. and Sreenivasulu, R. 1988b. Effect of $\mathrm{N}$ and $\mathrm{P}_{2} \mathrm{O}_{5}$ on flowering and yield of marigold (Tagetes erecta L). South Indian Horticulture, 36(6): 321-323.

Arulmozhiyan, R. and Pappaiah, C. M. 1989. Studies on the effect of nitrogen, phosphorus and ascorbic acid on the growth and yield of marigold (Tagetes erecta L) cv MDU-1. South Indian Horticulture, 37(3): 169-172.

Belorkar, P. V., Patel, B. N., Golliwar, V. J. and Kothare, A. J. 1992. Effect of nitrogen 
and spacing on growth, flowering and yield of African marigold. Journal of Soils and Crops, 2: 62-64.

Beata K. 2011. The effect of different nitrogen fertilization Rates on yield and quality of marigold (calendula officinalis L. 'tokaj') raw material. Acta Agrobotanica, 64 (3): 29-34.

Bose, T. K. and Yadav, L. P. 1998. Merigold: In Commercial flowers, ( $2^{\text {nd }}$ edn.). Noya Prokash Calcutta, India, 713-731 pp.

Das, D, K. and Mandal, M. 2016. Advance technology of fertilizer uses for crop production. In Book: Fertilizer Technology-I Synthesis, ( $1^{\text {st }}$ ed.), Studium Press, LLC, USA, 101-150 pp.

Dobermann, A. and Fairhurst, T. 2000. Economics of fertilizer use. In Rice: Nutrient disorder and nutrient management. Potash and phosphate Institute, Canada and International Rice Research Institute, Philippines. 38 p.

Haque, I. and Jakhro, A. A. 2001. Soil and fertilizer potassium. In "Soil Science" National Book Foundation, Islamabad, Pakistan. 261-263 pp.

Henry, D. 1982. Effect of potassium on plant growth. Journal of Ornamental Horticulture Science, 6:320-321.

Hunter, A. H. 1984. Soil fertility analytical services in Bangladesh. Consultancy Report. Bangladesh Agricultural Research Project- Phase II. BARC, Dhaka, Bangladesh.

Jackson, M. L. 1958. Soil chemical analysis. Constable and Co. Ltd., London. 64 p.

Khan, F. N., Rahman, M. M., Karim, A. J. M. S. and Hossain, K. M. 2012. Effects of nitrogen and potassium on growth and yield of gladiolus corms. Bangladesh Journal of Agricultural Research, 37(4): 607-616.

Khan, M. A., Malik, A. B., Khan, M. N. and Saeed, T. 1999. Nitrogen fertilizer in
Zinnia elegans in pot culture. Pakistan Journal of Scientific Research, 3: 81-84

Konnerup, D. and Brix, H., 2010. Nitrogen nutrition of Canna indica. Effects of ammonium versus nitrate on growth, biomass allocation, photosynthesis, nitrate reductase activity and $\mathrm{N}$ uptake rates. Aquatic Botany, 92: 142-148.

Lodhi, A. K. S. and Tiwari, G. N. 1993. Nutritional requirement of chrysanthemum under field condition. Fertilizer News, 38(3): 39-45.

Mishra, H. P. 1998. Effect of nitrogen on growth and flowering of Gaillardia. Indian Journal of Ornamental Horticulture, 1: 41-47.

Pandey, R. K. and Mishra, A. 2005. Effect of nitrogen, phosphorus and potassium on growth, flowering and seed yield in marigold cv Pusa Narangi Gainda. Progressive Horticulture, 37(2): 341-344.

Priyanka, D, Shalini, T. and Navneet, V. K. 2013. A brief study on marigold (Tagetes species). International Research Journal of Pharmacy, 4(1):43-48.

Steel, R. C. B. and Torrie. J. H. 1960. McGraw Hall Book, New York, USA. Principles and producers of statistics, 377-398 pp.

Vaněk, V., Balík, J., Černý, J., Pavlík, M., Pavlíková, D., Tlustoš, P. and Valtera, J. 2012. Academic Press, Prague. The Nutrition of Horticultural Plants, 568 p.

Yadav, L. P. and Bose, T. K. 1998. Effect of planting time, plant density and nutrition on growth and flowering in marigold. South Indian Horticulture, 45(3): 222225 .

Zhang, W., Li, X., Chen, F. and Lu, J. 2012. Accumulation and distribution characteristics for nitrogen, phosphorus and potassium in different cultivars of Petunia hybrida Vlim. Science in Horticulture, 141: 83-90. 